\title{
AN OVERVIEW OF THE ANTI CORRUPTION LAWS IN ROMANIA. ELEMENTS OF COMPARED LAW
}

\author{
M.M. Bârsan \\ Transylvania University of Brasov, LawSchool \\ Maria Magdalena Barsan, Transylvania University of Brasov, Law School, Eroilor \\ Street, No. 25, Brasov, Romania \\ magdalena_maria_neagu@yahoo.com
}

\begin{abstract}
In the introduction of this paper, we will discuss the general aspects of the phenomenon of corruption in contemporary society. Furthermore, the article aims to briefly analyze the anti corruption laws in Romania, but also to to discuss the corruption crimes as regulated by the Criminal Code and other special laws. We will also present important aspects of the anti corruption laws in countries such as Belgium, Germany, Spain, France by directly referring to the corruption crimes as regulated in the laws of those countries.

Key words: corruption, public office, crime, Criminal Code, bribery.

\section{Introduction}

The history of human society shows that the criminal phenomenon of corruption has existed from the oldest times and started to manifest under different forms, thus becoming a scourge of contemporary society. We can appreciate that the phenomenon of corruption is of the same age as humanity, as it manifested in any human society; the possibility of removing it is rather hard to achieve. This criminal phenomenon manifests in the present times in all the states of the world and in all social structures, regardless of the social system or the level of economical development, with times of calm and recrudescence, depending on the socialpolitical, economical changes as well as the way this phenomenon was approached by the state power organisms. Each country has its own history and culture, its own political system and set of social values and each is found in a different stage of evolution from all points of view. Keeping these facts in mind, it is possible that an anti corruption solution applied in one country may not work in another country. However, the experience of a general solution can offer solutions which will apply in other countries.

The laws on corruption are likely to create confusion, given the speedy development of the ways in which corruption crimes can be committed. Thus, changing the laws on corruption became more and more necessary. In a world characterized by the extreme mobility of structures, the lawmaker must take into account the needs of society and he must continuously adapt the laws to the current stage of development. Given the defective laws and the continuous change of society, from an economical, social-political point of view, Law no $78 / 2000$ for preventing, investigating and sanctioning corruption ${ }^{1}$ was passed, a law meant to incriminate the crimes of corruption in a modern manner and to provide greater attention to the corruption phenomenon on all levels.

The national law regulates in the Criminal Code, title V "Corruption crimes" the crimes of receiving bribe, offering bribe, influence peddling and acquisition of influence. Law no 78/2000 completes the Criminal Code and incriminates a series of crimes assimilated to corruption crimes and crimes against the financial interests of the European Union (art.10$18^{5}$ ), but these are not the object of out analysis, as we will discuss the corruption crimes regulated in the Criminal Code (articles 289-292 of the Criminal Code).
\end{abstract}

\footnotetext{
${ }^{1}$ Law 78/2000 for preventing, investigating and sanctioning corruption, published in the Official Bulletin, part I, no 219 of May $18^{\text {th }}, 2000$, with subsequent changes and additions.
} 


\section{AN OVERVIEW OF THE ANTI CORRUPTION LAWS IN ROMANIA. ELEMENTS OF \\ COMPARED LAW}

The crime of receiving bribe has existed for many centuries. There is no specific definition, but the next points are generally accepted as the equivalent of a definition: (i) claiming, receiving or accepting; (ii) an undue reward (money or other advantages); (iii) by a public officer; (iv) in order to influence the professional behavior or in order to determine that person to act contrary to the rules (fulfilling, not fulfilling, the speeding or delaying of an act which represents a professional duty or in regard to performing an act contrary to his duties).

The action or inaction which forms the material element of the crimes of receiving bribe must meet the all of following conditions:

1. The object of the deed must be money or other patrimonial or non patrimonial advantages which the perpetrator is not legally entitled to, advantages which must be claimed, received or accepted for himself or for others.

2. The money or advantages which are claimed or accepted are not legally owed to that person

3. The act for which the money or advantages are claimed, received or accepted represents a professional duty for the public officer, thus it must be an act regarding his duties or an act contrary to those duties.

4. The money or advantages are claimed, received or accepted for himself or for others.

The crime of offering bribe can only exist if the all of the following conditions are met:

1. The promising, offering or giving bribe consists of money or other advantages.

2. The money or advantages which are promised, offered or given are undue.

3 . The money or advantages are given or promised are meant for that specific person or for a third person.

4. The act for which the active subject promises, offers or gives money or other advantage is an act regarding the professional duties of the public officer or an act contrary to those duties.

In order to be in the presence of influence peddling the following conditions must be met:

1. The active subject must have influence or he must lead people to believes he has influence over the public officer.

2. The active subject must promise to intervene on behalf of the subject in order to determine a public officer or a person which performs a duty in a company to determine him to fulfill, to not fulfill, to speed or delay the fulfilling of an act which represents his professional duties or to perform an act which is contrary to those duties $^{2}$.

3. The action which represents the material element of the crime must be accomplished before the public officer performed the act which is the object of the intervention or, at the latest, while the act is being performed.

In order to complete the objective side of the crime of acquisition of influence, the following conditions must be met:

1. Any way in which this crime is committed (offering, promising, giving) must be committed as a result of the influence the seller claims to have over a public officer or over a person of those stated in article 308 of the Criminal Code.

2. The action which forms the material element must be committed by the author for the intervention of the seller over a public officer or the person stated in article 308 of the Criminal Code, thus causing him to fulfill, not fulfill, speed

\footnotetext{
${ }^{2}$ http:www.just.ro/Portals/0/Coduri/dezbateri/cuprins\%20si\%20partea\%20de\%20penal.doc
} 


\section{M.M. Bârsan}

or delay the performing of an act which is his professional duty or to perform an act contrary to his duties.

3. The action which forms the material element of the crime must be achieved before the public officer or the person regulated by article 308 of the Criminal Code performs the act which represents his professional duty or, at the latest, while performing the act.

In continuing with our work, we will discuss the corruption crimes regulated in the laws of other European countries, such as: Belgium, France, Germany, the Netherlands and Spain.

In the Belgian Criminal Code, the bribing of a public officer is illegal, namely offering, promising, whether direct or indirect, an advantage of any kind to a public officer to his benefit or to the benefit of another person, in order to influence the behavior of that public officer. To request or accept bribe, whether direct or indirect, is also illegal. Bribe offered to people in the private sector is also illegal. This consist of offering or promising an advantage of any kind, directly or indirectly, to a person who is the manager or representative of a company in order to influence that person to perform an action or not to perform an action in regard to his work, an action which is not known or authorized by his superiors.

The French Criminal Code forbids any action of suggesting, implying, directly or indirectly, offering, promising or giving an advantage of any kind to a public officer or to a person who holds a public office or is the winner of an election, in a foreign country or within an international organization, for himself or for another person, so as the relevant person abstains from performing an act according to his duties. It is also forbidden for any person to offer consent in committing a crime of corruption or to solicit or accept bribe. Also, in France it is forbidden to peddle influence in order to obtain contracts of favorable decisions from public institutions.

The corruption of a public officer is illegal, according to the provisions of the German Criminal Code. A person who offers, promises or gives an advantage to a public officer in order to fulfill an act contrary to his professional duties is punished (giving bribe, section 334 of the Criminal Code: the person who offers, promises or gives a public officer, a person especially empowered or a member of the federal army, an advantage, for himself or for another person, as a counter favor for an act he performed or will perform as a result of the position he is in and for which he will violate his professional duties, is punished. If a person offers, promises or gives a judge or an arbiter an advantage, for himself or for another person, as a counter favor, for a legal action: 1. Which he fulfilled, thus violating his professional duties or 2. An action which he will fulfill and for which he might violate his professional duties, that person is punished with imprisonment from 3 months to 5 years). Also, providing an advantage is punished, according to section 333 of the Criminal Code: the deed of the person who offers, promises or gives a public officer, a person especially empowered by a public body or a member of the federal army, an advantage, for himself or for another person, in order to fulfill an act which is possible given the position of that person.

The court will punish a person who offers, promises or gives a judge or an arbiter an advantage, for himself or for another person, as a counter favor for a legal action which he fulfilled or will fulfill, with a fine or imprisonment for up to 5 years. The public officer is criminally liable in case he accepts the promised or offered advantages (sections 331 and 332 of the Criminal Code).

Article 331 of the German Criminal Code sanctions the receiving of undue advantages, a crime with the following content: the deed of the public officer or the person especially empowered by a public body who claims, accepts or receives an advantage, for himself or for another person, in order to fulfill an act which is possible given his position, 


\section{COMPARED LAW}

with imprisonment for up to 3 years of a fine ${ }^{3}$.

The judge or the arbiter who claims, accepts or receives an advantage, for himself or for another person, as a counter favor, for a legal action which he undertook or will undertake, is punished with a fine or imprisonment of up to 5 years. The attempt is also punished.

Article 332 incriminates receiving bribe as the deed of the public officer or the person especially empowered by a public body, who claims, accepts or receives an advantage, for himself or for another person, as a counter favor for the fact that he fulfilled or will fulfill an act made possible by his position and which would cause him to violate his professional duties; this deed is punished with imprisonment for up to 3 years or a fine ${ }^{4}$. The attempt is also punished.

The judge or arbiter who claims, accepts or receives an advantage, for himself or for another person, as a counter favor for a legal action he undertook or will undertake, thus causing him to violate his professional duties, will be punished with imprisonment between 1 year and 10 years. In cases with less severe consequences, the punishment is imprisonment from 6 months to 5 years 5 .

According to the Dutch Criminal Code, it is forbidden to offer a gift or to perform a favor for a public office, including a person who is about to become a public officer, in order to determine him to perform an action or abstain from performing an action (past, present or future) regarding his professional duties. The same provisions apply in case a gift is offered as a reward for an action of the public officer in regard to his professional duties, regardless of whether these actions represent a violation of his duties or not. Furthermore, it is forbidden for another person, except the public officer ("a person from the private sector"), whether employed of acting based on a special empowering, to accept a gift or the promise of a gift as a reward for his actions or inactions, as well as the action of concealing the acceptance of a gift or the promise of a gift from his employer, in bad faith.

Article 419 of the Spanish Criminal Code regulates corruption which involves public officers:

- it is illegal to corrupt or attempt to corrupt a Spanish public officer by promising gifts and/or by offering goods in order to obtain the execution of an incorrect act or the omission to perform an act in relation to that public officer's duties; it is also illegal to accept the promise of a gift in order to achieve the above mentioned purposes.

Article 445 of the Spanish Criminal Code regulates the deeds of corruption which involve foreign authorities or foreign public officers. It is illegal to corrupt or attempt to corrupt a foreign authority or a foreign public officer by promising gifts, presents or offering other goods in order to obtain a contract or any other unjust benefit in the context of an international economical activity or to accept the promise of a foreign public authority or foreign public officer in order to obtain the above mentioned purposes.

Thus, offering gifts or promises to a foreign public authority or to public officers will be considered a crime only if the purpose of the bribe is to obtain or maintain a contract or any other benefit in the context of an international economical activity.

Any other type of bribe is considered a crime, according to Spanish law.

\section{Conclusion:}

The key of the anti corruption fight is to combine prevention measures with repressive measures, as repression without prevention does not reach the final goal, while prevention

\footnotetext{
${ }^{3}$ www.cristidanilet.ro/continut/carti-monografii/2009-coruptia-in $\quad$-sistemul-juridic/137-05-politici-anticoruptiepentru-sistemul-juridic

${ }^{4}$ www.docs.juridice.ro/Codul-penal-precizari-MCJL.doc

${ }^{5}$ http:www.just.ro/Portals/0/Coduri/dezbateri/cuprins\%20si\%20partea\%20de\%20penal.doc
} 


\section{M.M. Bârsan}

without repression is not efficient. Corruption, regardless of how we would define it, can't be removed from society. It will resist, as it is motivated by two essential aspects of human nature: need and greed. However, it can be reduced and maintained at a certain level in order to not affect society. Also, corruption can't be fought unless the general population becomes aware that the leaders are truly willing to fight corruption and officials from the highest levels prove they are honest and sincere and that economical development is in the benefit of the lower categories of society. In order to draw a conclusion, we can state that the need for corrupt activities in a society can be removed. With the help of the community, greed can be fought and kept under control.

\section{References:}

1. C. Danilet, Corruption and anti-corruption in the judiciary, Publishing House C.H.Beck, Bucharest, 2009

2. www.just.ro

3. http://www.scrigroup.com/legislatie/Proiectul-Noului-Cod-Penal72121.php

4. The German Criminal Code

5. The French Criminal Code

6. The Spanish Criminal Code

7. The motivation of Law no.135 of June 1st, 2010 regarding the Criminal Procedure Code was published in the Official Bulletin of Romania, Part I, no. 486 of July 15st, 2010 with subsequent changes and additions.

8. www.cristidanilet.ro/continut/carti-monografii/2009-coruptia-in-sistemul-juridic/137-05politici-anticoruptie-pentru-sistemul-juridic

9. www.docs.juridice.ro/Codul-penal-precizari-MCJL.doc

10. http:www.just.ro/Portals/0/Coduri/dezbateri/cuprins\%20si\%20partea\%20de\%20penal.doc

11. Law 78/2000 for preventing, investigating and sanctioning corruption, published in the Official Bulletin, part I, no 219 of May 18th, 2000, with subsequent changes and additions.

12. Law no. 135 of 1 July 2010 on the Criminal Procedure Code, published in the Official Gazette, Part I, no. 486 of 15 July 2010

13. The Belgian Criminal Code

14. See Explanatory Memorandum on the draft Law on the Criminal Code, http://www.just.ro 